\title{
ВЛИЯНИЕ МИГРАЦИИ НА ЧИСЛЕННОСТЬ И ВОЗРАСТНОЙ СОСТАВ НАСЕЛЕНИЯ МУНИЦИПАЛЬНЫХ ОБРАЗОВАНИЙ РАЗНЫХ ТИПОВ В БАШКОРТОСТАНЕ
}

\author{
НАИЛЯ ШАМСУТДИНОВА, ВАДИМ ПРУДНИКОВ, \\ ИРИНА УТЯШЕВА, ГУЛЬДАР ХИЛАЖЕВА
}

\begin{abstract}
В статье произведена оценка вклада миграции в изменение численности и возрастной структуры населения различных типов муниципальных образований Республики Башкортостан. Среди таких типов выделены ядра (промышленные и образовательные центры, притягивающие человеческий капитал), тяготеющие к ядрам муниципалитеты, численность населения которых растет за счет влияния ядер (пригородные территории), а также периферийные районы, миграция из которых в предель Уфимской и Южно-Башкортостанской агломераций носит безвозвратный характер. На первом этапе выполнен ретроспективный прогноз для представителей трех выделенных типов муниципальных образований на период 2008-2018 г2. Согласно его результатам наибольиий выигрыш миграчия принесла не ядрам, а тяготеющим к ним пригородным муниципальным образованиям, что отразилось в приросте численности их населения практически во всех возрастных группах, но прежде всего населения предпенсионного и пенсионного возраста. На втором этапе проведено сценарное прогнозирование численности населения муниципальных образований на период до 2029 г. Вылелены четыре сценария развития миграционной ситуации. Результаты прогнозирования указывают на то, что прирост численности населения ядер агломераций и их пригородных территорий возможен только за счет продолжения миграциинного притока, который, однако, не окажет значительного влияния на возрастную структуру. В то же время периферийные муниципальные районы, продолжая терять население, значительно «постареют». Таким образом, развитие ядер и пригородных территорий тесно сопряжено с потерей демографического потенциала отдающими население периферийными территориями. В результате в среднесрочной перспективе в Республике Башкортостан ожидается замедление прироста численности населения центров агломераций.
\end{abstract}

Ключевые слова: миграчионный прирост, возрастная структура, прогнозирование, Уфимская агломерачия, Южно-Башкортостанская агломерачия, ядро, периферия.

\section{ВВЕДЕНИЕ}

Закономерности динамики численности и возрастной структуры населения населенных пунктов любого размера невозможно рассматривать вне процесса урбанизации и без учета универсальных стадий этого процесса (Gibbs 1963: 85-99; Klaassen, Schimemi 1981: 8-28.)

НАИЛЯ КАДЫМОВНА ШАМСУТДИНОВА (shamsutdinovank@gmail.com), ИНСТИТУТ СТРАТЕГИЧЕСКИХ ИССЛЕДОВАНИЙ РЕСПУБЛИКИ БАШКОРТОСТАН, РОССИЯ.

ВАДИМ БОРИСОВИч ПРУДНИКОВ (prudnikov.bgu@mail.ru), БАШКИРСКИЙ ГОСУДАРСТВЕННЫЙ УНИВЕРСИТЕТ, Россия.

ИРИНА БОРИСОВНА УТЯШЕВА (utasheva@bashstat.ru), ИНСТИТУТ СТРАТЕГИЧЕСКИХ ИССЛЕДОВАНИЙ РЕСПУБЛИКИ БАШКОРТОСТАН, РОССИЯ.

ГУЛЬДАР ФАРИТОВНА ХИЛАЖЕВА (aguldar@yandex.ru), ИНСТИТУТ СТРАТЕГИЧЕСКИХ ИССЛЕДОВАНИЙ РЕСПУБЛИКИ БАШКОРТОСТАН, РОССИЯ.

СТАТЬЯ ПОДГОТОВЛЕНА ПРИ ПОДДЕРЖКЕ РФФИ И РЕСПУБЛИКИ БАШКОРТОСТАН, ПРОЕКТ №17-46-020237 «ИССЛЕДОВАНИЕ ТЕНДЕНЦИЙ И ФАКТОРОВ, ВЛИЯЮЩИХ НА ПРОСТРАНСТВЕННОЕ РАСПРЕДЕЛЕНИЕ ЧЕЛОВЕЧЕСКОГО КАПИТАЛА КАК ЭЛЕМЕНТА СИСТЕМЫ ВЗАИМОДЕЙСТВИЯ ЦЕНТРА И ПЕРИФЕРИИ (НА ПРИМЕРЕ РЕСПУБЛИКИ БАШКОРТОСТАН)».

СТАТЬЯ ПОСТУПИЛА В РЕДАКЦИЮ В МАЕ 2020 Г. 
Теории урбанизации концентрируются на выявлении закономерностей взаимодействия центра-пригорода, городских центров и периферии, а также сельскогородского континуума (Трейвиш 2016: 52-70). Специфика советской модели урбанизации заключалась в форсированной индустриализации, наличии противоречий между количественными и качественными характеристиками, географическими, экономическими, социальными параметрами страны. В настоящее время Россия в целом характеризуется развитием региональных агломераций. Современными региональными центрами можно назвать города с населением свыше 250 тыс. человек (Зайончковская 2000: 1-15; Пивоваров 2001: 101-113; Нефедова, Трейвиш 2001: 171-194). Для России нехарактерно соподчиненное развитие крупных и средних городов, отмечается незавершенность урбанизации, во многих регионах степень урбанизации по-прежнему крайне низка, в том числе и в Республике Башкортостан (Карачурина 2012: 10-24). Миграция является движущей силой дифференциации, в одних случаях способствуя росту численности населения, в других - наоборот, являясь причиной ее снижения, деформируя половозрастную структуру населения. Крупнейшие города, являясь центрами агломерации, способствуют преломлению миграционного передвижения в «агломерационном поясе» (Карачурина, Мкртчян 2016: 46-59). Населенные пункты, находящиеся на периферии «агломерационного пояса», все больше теряют молодежь, а удельный вес старших возрастных когорт увеличивается. При этом данные процессы могут сдерживаться средними и малыми городами (Карачурина, Мкртчян 2014: 62-80). Ретроспективные оценки влияния миграции на численность молодежи городов и сел России с использованием данных переписей показали, что с 1979 по 1989 г. сельская местность России потеряла 34\% детей 5-9 лет и 26\% детей 10-14 лет (Мкртчян, Карачурина 2012: 688-707). Убыль и старение населения региона в целом не означают, что в то же время в его пределах не происходят процессы концентрации населения в региональном центре. Малые и средние города не способны удерживать население в условиях сокращения потока населения из сел. В то же время для сельских территорий характерно снижение общей численности и «постарение» населения. В сельских районах, расположенных за пределами зоны активной маятниковой миграции в региональные центры, снижается численность молодежи (с 2015 по 2019 г. темпы снижения численности сельской молодежи в возрасте от 15-19 до 30-34 лет составили в таких районах примерно 5-8\%).

\section{ЭКОНОМИЧЕСКОЕ ЗОНИРОВАНИЕ ТЕРРИТОРИИ РЕСПУБЛИКИ БАШКОРТОСТАН}

Географические факторы, исторические особенности расселения, а также сложившаяся система размещения промышленных предприятий в Республике Башкортостан повлияли на неравномерность социально-экономического развития территорий региона.

В пределах Башкортостана специалисты выделяют семь социально-экономических зон (субрегионов). Это центральный, южный, западный, северо-западный, северный, северо-восточный и уральский субрегионы, которые различаются уровнем социальноэкономического развития, степенью урбанизированности, характером протекающих социально-демографических процессов (Исянбаев 2008). 


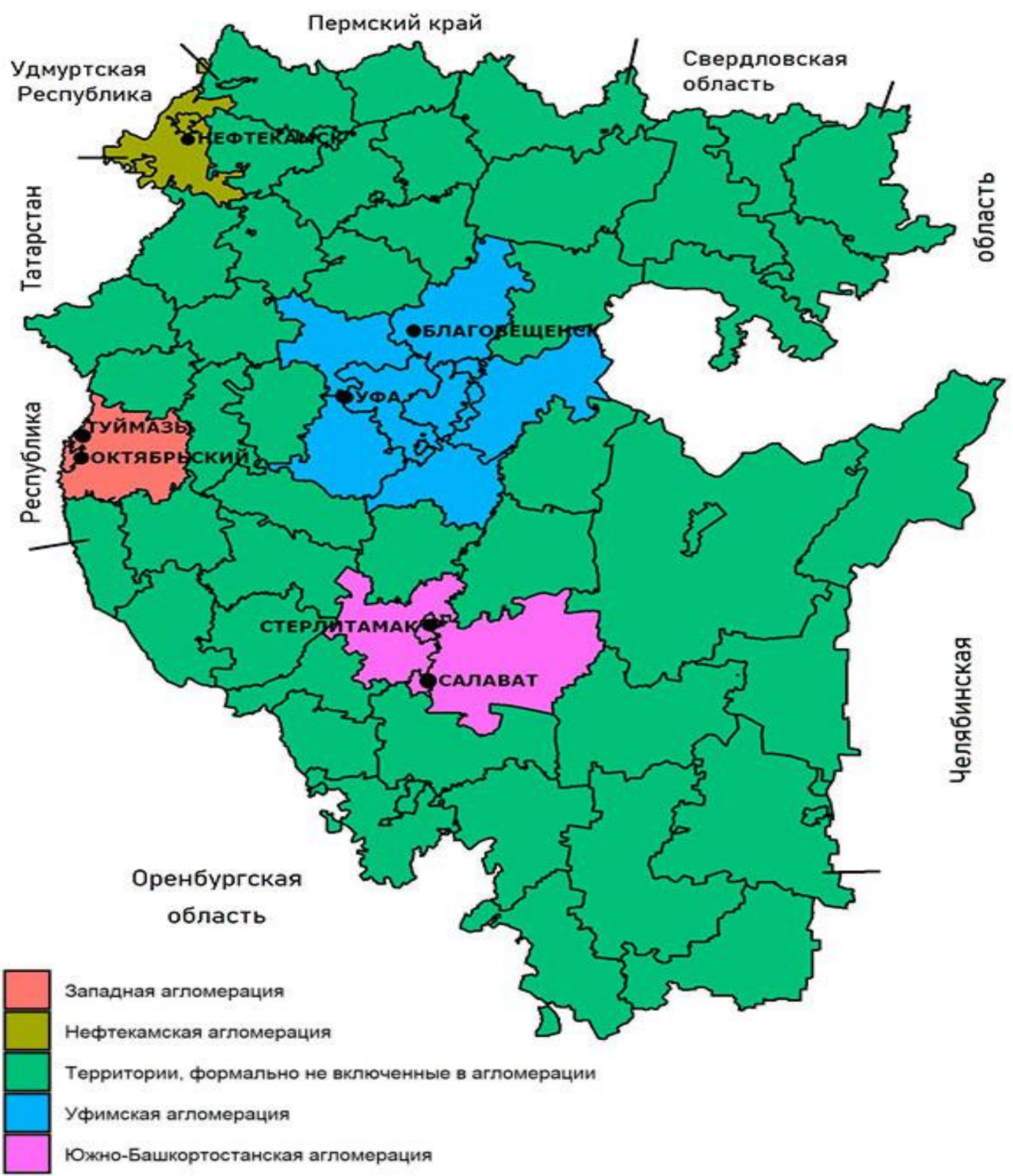

\section{Рисунок. Состав агломераций региона по муниципальным образованиям}

Источники: Стратегия социально-экономического развития Республики Башкортостан на период до 2030 2. ; ; экспертные оценки специалистов.

Центральный, южный и западный субрегионы, наиболее развитые в социальноэкономическом отношении, характеризуются относительно более благоприятной демографической ситуацией. В них сконцентрировано более $90 \%$ промышленного

\footnotetext{
${ }^{1}$ Утверждена Постановлением Правительства РБ от 20.12.2018 №624 «О Стратегии социальноэкономического развития Республики Башкортостан на период до 2030 года». URL:

https://minecon.bashkortostan.ru/dejatelnost/strategicheskoe-planirovanie/strategiya-razvitiya-respublikibashkortostan/strategiya-respubliki-bashkortostan-2030/
} 
потенциала региона, находятся 13 городов республики. Уровень социальноэкономического развития остальных субрегионов является относительно низким. Среди них уральский является слабоурбанизированным, а северный и северо-восточный практически неурбанизированными, на их территории отсутствуют городские населенные пункты.

Несмотря на то, что не существует общепринятого подхода к выделению агломераций среди административно-территориальных образований республики, в целом на территориях обозначенных субрегионов экспертами сегодня выделяются следующие четыре агломерации (Гайнанов, Уляева 2017):

1) в центральном субрегионе - Уфимская агломеращия, к которой относятся: городской округ Уфа, муниципальные районы Благовещенский, Иглинский,

Уфимский, Кармаскалинский, Чишминский, Кушнаренковский;

2) в южном субрегионе - Южно-Башкортостанская (Стерлитамакская) агломеращия: городские округа Стерлитамак, Салават, муниципальные районы Стерлитамакский, Ишимбайский;

3) в западном субрегионе - Западная (Октябрьско-Туймазинская) агломерация: городской округ Октябрьский и Туймазинский район с городом Туймазы.

4) в северо-западном субрегионе - Нефтекамская агломеращия: городские округа Нефтекамск, Агидель, Краснокамский район.

Географическое расположение агломераций представлено на рисунке.

\section{КРАТКАЯ ХАРАКТЕРИСТИКА МИГРАЦИОННЫХ ПРОЦЕССОВ В РЕГИОНЕ}

Миграционная ситуация в Республике Башкортостан является типичной для большинства российских регионов. В общем объеме валовой миграции, которая, в среднем за 2016-2018 гг., составила около 200 тыс. человек в год, наибольшая доля приходится на внутрирегиональную (48\%), затем - межрегиональную (42\%) и менее десятой части - на международную (9\%).

Показатели международной миграции, которые в республике всегда имели положительные значения, в последние годы стали снижаться и в 2016-2018 гг. стали отрицательными (Башкортостанстат 2019а).

Межрегиональная миграция в течение длительного периода ведет к ежегодной миграционной убыли населения (в 2016-2018 гг. - около 7,5 тыс. человек). При этом наиболее притягательным направлением для мигрантов из Башкортостана являются регионы европейской части страны (Москва, Санкт-Петербург). Кроме этого значительный миграционный отток наблюдается в соседние регионы Урало-Поволжья (Челябинская область, Республика Татарстан и др.), а также в сибирские регионы (прежде всего - в округа Тюменской области). Последние являются привлекательными в контексте не только долгосрочной, но и краткосрочной (временной трудовой) миграции. Башкортостан 
лидирует среди субъектов РФ по абсолютной численности мигрантов, временно работающих за пределами своих регионов (в 2019 г. - 160,7 тыс. человек) ${ }^{2}$.

Миграция в пределах республики носит центростремительный характер. Типичной является общероссийская модель, при которой население стягивается в более крупные городские и сельские поселения из менее населенных. В Башкортостане наиболее интенсивным является миграционный прирост регионального центра - городамиллионника Уфы и его пригородов, при этом пригороды характеризуются более интенсивным миграционным приростом, чем сама столица (Мкртчян 2020).

\section{ДАННЫЕ}

Для реализации ретроспективного прогноза были использованы следующие исходные данные Территориального органа Федеральной службы государственной статистики по Республике Башкортостан (далее - Башкортостанстат) по отобранным для исследования муниципальным образованиям:

- возрастно-половая структура населения за период с 1 января 2005 по 1 января 2019 г.;

- численность родившихся по полу в отобранных муниципалитетах за 2005-2018 гг.;

- численность умерших по полу и возрасту за 2005-2018 гг.;

- миграционный прирост по полу за 2005-2018 гг.

Для реализации перспективного прогноза были использованы следующие данные:

- возрастно-половая структура населения на 1 января 2019 г.;

- возрастные коэффициенты рождаемости в среднем за период 2017-2018 гг.

(Башкортостанстат 2019b: 66-74);

- возрастные коэффициенты смертности за 2018 г., рассчитанные по данным Башкортостанстата.

За указанные периоды для реализации ретроспективного прогноза были рассчитаны возрастные коэффициенты рождаемости и коэффициенты передвижки. Для реализации перспективного прогноза были разработаны три сценария миграции.

\section{ПОСТАНОВКА ЗАДАЧ И МЕТОДЫ}

Цель проведенного исследования заключалась в оценке вклада миграции в изменение численности и возрастной структуры населения муниципальных образований Республики Башкортостан разных типов в пределах Уфимской и Южно-Башкортостанской агломераций.

Авторами выделены три типа муниципальных образований: ядра, притягивающие человеческий капитал - промышленные и образовательные центры; муниципальные

\footnotetext{
2 Башкортостанстат (2020). Трудовая миграция жителей Республики Башкортостан в 2019 г. Пресс-выпуск, 08.04.2020.
} 
образования, тяготеющие к ядрам, численность которых растет за счет его влияния (непосредственно примыкающие к ядрам пригородные территории); наконец, периферийные районы, миграция из которых носит безвозвратный характер (Ахметова и др. 2019). К первому типу в рамках Уфимской агломерации относится региональный центр (г. Уфа, 1,13 млн человек на начало 2020 г.), муниципалитеты в пределах маятниковой доступности - Уфимский и Благовещенский районы (91,4 и 14,3 тыс. человек соответственно), город-спутник Благовещенск (35,0 тыс.), периферийный Караидельский район (25,3 тыс.), не входящий в Уфимскую агломерацию непосредственно; ЮжноБашкортостанскую агломерацию представляют крупный город-ядро Стерлитамак (279,6 тыс.), Стерлитамакский район (43,0 тыс.), а также тяготеющий к ней, но периферийный Федоровский район (16,8 тыс. человек).

В рамках исследования были запланированы и решены следующие задачи:

- выполнение ретроспективного прогноза - измерение вклада миграции в изменение численности и возрастной структуры рассматриваемых муниципальных образований за период 2007-2017 гг.;

- $\quad$ выполнение перспективного прогноза - прогнозирование численности и возрастной структуры по инерционному, оптимальному, умеренному сценариям на период до 1 января 2029 г.

Прогнозирование выполнено когортно-компонентным методом.

Для решения первой задачи в качестве сценарных условий было принято сохранение параметров рождаемости и смертности на фактическом уровне, который наблюдался бы в отобранных муниципальных образованиях при гипотетическом отсутствии в них миграционного прироста с 2007 по 2017 г. включительно.

Для решения второй задачи в качестве сценарных условий были приняты сохранение параметров рождаемости в среднем за 2017-2018 гг. и смертности на уровне 2018 г. При этом были разработаны инерционный, умеренный, оптимальный сценарии миграции, учитывающие динамику миграционного прироста по возрасту и полу на период до 2029 г. Для периферийных Федоровского, Караидельского, Благовещенского районов характерны общие тенденции социально-экономического, демографического развития, в частности, миграция из сельских населенных пунктов данных районов в близлежащие агломерации носит безвозвратный характер. В связи с этим для данных районов был разработан один общий сценарий разворачивания миграции.

Ниже представлено описание предложенных авторами сценариев (инерционного, умеренного, оптимального) пространственного распределения населения Республики Башкортостан и предпосылок их реализации.

1. Инерционный. Характеризуется продолжением и усилением тренда концентрации населения в целом, в том числе высококвалифицированных трудовых ресурсов, в Уфимской агломерации и потери его на периферийных территориях. 
2. Умеренный. Предусматривает усиление полицентричности распределения человеческого капитала в республике за счет появления новых центров внутрирегиональной миграции.

3. Оптимальный. Характеризуется рассредоточенным развитием Уфимской, Южно-Башкортостанской, Западной агломераций, а также городов Сибай и Нефтекамск как ядер для своих полупериферий (Ахметова и др. 2019).

В рамках исследования предполагаются негативные миграционные тренды периферийных малозаселённых территорий для всех сценариев прогноза.

\section{РЕЗУЛЬТАТЫ РЕТРОСПЕКТИВНОГО ПРОГНОЗА}

Ядра агломераций ожидаемо испытали влияние миграции, которая способствовала не только росту численности, но и внесла ощутимый вклад в «омоложение» возрастной структуры. Положительное влияние испытал и город-спутник регионального центра Благовещенск, который прирастил свою численность за счет миграции на 4,1\% при сопоставимой с другими периферийными территориями потере ее в Благовещенском районе (без учета населения города). Влияние ядра особенно проявляется в намного более заметном приросте численности населения пригородных территорий - Уфимского и Стрелитамакского районов. В первом из них без миграции прирост составил бы около $1 \%$, во втором его не было бы вовсе. В то же время постоянный приток жителей в пригородные территории указанных городов позволил им нарастить их число на 52,5 и 28,4\% соответственно. Сводные результаты ретропрогнозирования для всех возрастных групп представлены в таблице 1. В отдельном столбце приведен эффект миграции, отклонение фактической численности от прогнозируемой.

Таблица 1. Численность населения факт/прогноз, на начало года

\begin{tabular}{l|c|c|c|r}
\hline & $\begin{array}{c}\text { 2007, факт, тыс. } \\
\text { человек }\end{array}$ & $\begin{array}{c}\text { 2018, факт, тыс. } \\
\text { человек }\end{array}$ & $\begin{array}{c}\text { 2018, прогноз, } \\
\text { тыс. человек }\end{array}$ & $\begin{array}{c}\text { Эффект } \\
\text { миграции, \% }\end{array}$ \\
\hline Уфа & 1028,68 & 1131,43 & 1056,34 & 7,11 \\
Стерлитамак & 268,31 & 279,62 & 275,62 & 1,45 \\
Благовещенский район & 15,33 & 14,26 & 15,88 & $-10,20$ \\
Благовещенск & 33,64 & 35,01 & 34,55 & 1,33 \\
Караидельский район & 27,95 & 25,29 & 28,28 & $-10,57$ \\
Федоровский район & 19,82 & 16,80 & 19,04 & $-11,76$ \\
Уфимский район & 59,96 & 91,41 & 60,53 & 51,02 \\
Стерлитамакский район & 33,48 & 42,98 & 33,3 & 29,07 \\
\hline
\end{tabular}

Источник: Расчеты авторов.

Наибольший «выигрыш» в молодых возрастных группах миграция снова принесла пригородным территориям. В возрастных группах до 34 лет прирост составил от 18,2\% в Стерлитамакском районе до почти $45 \%$ в Уфимском, в то время как без миграции он бы составил около 8 и 2\% соответственно. Если бы за период 2007-2018 гг. миграция отсутствовала, прирост числа детей и подростков (0-19 лет) в региональном центре составил бы всего 7,5\%, в то время как фактически он оказался равным 18,2\%; численность молодежи (20-34 года) и вовсе бы сократилась на 15,3\%, в то время как фактически выросла 
на 8\%. Аналогичная ситуация наблюдается в Стерлитамаке и Благовещенске в возрастной группе до 19 лет.

Наибольшее влияние на демографический потенциал территории, вероятно, оказывает динамика миграции населения в возрастной группе 20-34 года. Если для Стерлитамака в данной возрастной группе зафиксирован прирост, до в Благовещенске миграционная убыль, как и в Благовещенском и других периферийный муниципальных районах (Федоровском, Караидельском и др.), транспортная связность которых с экономическими центрами ограничена. При этом следует отметить, что миграция из периферийных территорий в экономические центры республики (Уфа, Стерлитамак) формирует прирост населения не только в городах, но прежде всего в их пригородных территориях.

Таблица 2. Численность населения по возрастным группам, факт/прогноз, на начало года, 2007-2018

\begin{tabular}{|c|c|c|c|c|}
\hline & $\begin{array}{c}\text { 2007, факт, } \\
\text { человек }\end{array}$ & $\begin{array}{c}\text { 2018, факт, } \\
\text { человек }\end{array}$ & $\begin{array}{c}2018, \\
\text { прогноз, } \\
\text { человек }\end{array}$ & $\begin{array}{c}\text { Эффект } \\
\text { миграции, \% }\end{array}$ \\
\hline \multicolumn{5}{|c|}{ Возрастная группа 0-19 лет } \\
\hline Уфа & 225159 & 266223 & 242044 & 9,99 \\
\hline Стерлитамак & 63779 & 69259 & 66907 & 3,52 \\
\hline Благовещенский район & 8550 & 9581 & 9220 & 3,92 \\
\hline г. Благовещенск & 4120 & 3578 & 4620 & $-22,55$ \\
\hline Караидельский район & 7591 & 6033 & 7599 & $-20,61$ \\
\hline Федоровский район & 4948 & 3481 & 4240 & $-17,90$ \\
\hline Уфимский район & 14138 & 20484 & 14404 & 42,21 \\
\hline Стерлитамакский район & 8344 & 9703 & 8137 & 19,24 \\
\hline \multicolumn{5}{|c|}{ Возрастная группа 20-64 лет } \\
\hline Уфа & 675910 & 725092 & 671279 & 8,02 \\
\hline Стерлитамак & 174556 & 177813 & 176248 & 0,89 \\
\hline Благовещенский район & 21970 & 21878 & 21880 & $-0,01$ \\
\hline г. Благовещенск & 8912 & 8583 & 9140 & $-6,09$ \\
\hline Караидельский район & 15978 & 15780 & 16917 & $-6,72$ \\
\hline Федоровский район & 11421 & 10370 & 11933 & $-13,10$ \\
\hline Уфимский район & 39420 & 59824 & 39050 & 53,20 \\
\hline Стерлитамакский район & 20263 & 27535 & 20837 & 32,14 \\
\hline \multicolumn{5}{|c|}{ Возрастная группа $65+$ лет } \\
\hline Уфа & 127602 & 140114 & 143017 & $-2,03$ \\
\hline Стерлитамак & 29968 & 32554 & 32464 & 0,28 \\
\hline Благовещенский район & 3119 & 3549 & 3453 & 2,78 \\
\hline г. Благовещенск & 2298 & 2096 & 2119 & $-1,09$ \\
\hline Караидельский район & 4386 & 3469 & 3758 & $-7,69$ \\
\hline Федоровский район & 3452 & 2947 & 2860 & 3,04 \\
\hline Уфимский район & 6404 & 11095 & 7076 & 56,80 \\
\hline Стерлитамакский район & 4869 & 5741 & 4323 & 32,80 \\
\hline
\end{tabular}

Источник: Расчеты авторов.

Несколько другая картина наблюдается в более старших возрастных группах. В целом миграция смягчает потери Караидельского и Благовещенского районов и почти не влияет на динамику населения в Уфе и Стерлитамаке в группе 35-49 лет, при этом значительно способствуя приросту численности населения пригородных территорий. В последних наиболее значительным был вклад миграции в прирост численности возрастной группы 50-64 года (рост в 2 раза). Развитие Уфимской и Южно- 
Башкортостанской агломераций за последнее десятилетие сопряжено прежде всего со значительным приростом численности молодого и пожилого населения в муниципальных районах, непосредственно являющихся пригородными территориями их центров. Миграция способствует увеличению прироста численности населения, прежде всего детей и молодежи до 19 лет, в городах Уфа и Стерлитамак, смягчая рост доли пожилых лиц и «постарение» населения. Периферийные муниципальные районы, напротив, теряют молодое население, что ожидаемо способствует старению, которое ускоряется и вследствие возвратной миграции лиц старших возрастных групп (таблица 2).

\section{РЕЗУЛЬТАТЫ ПЕРСПЕКТИВНОГО ПРОГНОЗА}

Наиболее высокое значение миграционного прироста способствует росту численности при всех сценариях в ядре Уфимской агломерации - г. Уфа и пригородном Уфимском районе, а также в Стерлитамакском районе, граничащем с г. Стерлитамак, экономическим центром Южно-Башкортостанской агломерации. Наиболее заметен рост в г. Уфа и Уфимском районе, где прирост численности населения к 2029 г. составит от 1,7 и 19\% при оптимальном до 2,3 и 25,6\% при инерционном сценарии соответственно.

Таблица 3. Прогноз численности населения муниципалитетов на период до 2029 г., на начало года (позитивная динамика), тыс. человек

\begin{tabular}{lcc|c}
\hline & 2018, факт & 2025, прогно3 & 2029, прогно3 \\
\hline \multicolumn{4}{c}{ Бера } \\
Без миграции & 1131,43 & 1136,33 & 1122,74 \\
Инерционный & 1131,43 & 1156,35 & 1162,11 \\
Умеренный & 1131,43 & 1154,34 & 1158,17 \\
Оптимальный & 1131,43 & 1152,54 & 1154,63 \\
Без миграции & Уфимский район & \\
Инерционный & 91,41 & 95,99 & 95,15 \\
Умеренный & 91,41 & 110,99 & 119,76 \\
Оптимальный & 91,41 & 109,49 & 117,30 \\
& 91,41 & 107,12 & 113,48 \\
Без миграции & Стерлитамак & \\
Инерционный & 279,62 & 274,83 & 269,92 \\
Умеренный & 279,62 & 270,05 & 267,05 \\
Оптимальный & 279,62 & 270,52 & 267,67 \\
& 279,62 & 270,95 & 268,26 \\
Без миграции & Стерлитамакский район & \\
Инерционный & 42,98 & 42,65 & 41,84 \\
Умеренный & 42,98 & 44,97 & 45,60 \\
Оптимальный & 42,98 & 44,74 & 45,22 \\
\hline
\end{tabular}

Источник: Расчеты авторов.

Несмотря на то, что Благовещенский район является точкой притяжения миграции, он скорее потеряет население (12,3\% при всех сценариях), которое стягивают как г. Благовещенск, так и г. Уфа. Численность населения самого Благовещенска при этом снизится на 3\%. В центре Южно-Башкортостанской агломерации городском округе Стерлитамак роста численности не ожидается, напротив, при всех сценариях прогнозируется снижение примерно на 4\%, при этом небольшой рост возможен в 
прилегающем к нему Стерлитамакском районе (до 5,2\%). Периферийные Федоровский и Караидельский районы продолжат терять население во всех рассматриваемых сценариях (18,3 и 13,7\% соответственно). Результаты прогнозирования численности рассматриваемых муниципалитетов приведены в таблице 3 (муниципалитеты с позитивной динамикой) и таблице 4 (муниципалитеты с негативной динамикой).

Таблица 4. Прогноз численности населения муниципалитетов на период до 2029 г., на начало года (негативная динамика), тыс. человек

\begin{tabular}{|c|c|c|c|}
\hline & 2018, факт & 2025, прогно3 & 2029, прогно3 \\
\hline \multicolumn{4}{|c|}{ Благовешенск } \\
\hline Без миграции & 35,01 & 34,72 & 34,30 \\
\hline Инерционный & 35,01 & 34,46 & 33,92 \\
\hline Умеренный & 35,01 & 34,46 & 33,92 \\
\hline Оптимальный & 35,01 & 34,46 & 33,92 \\
\hline \multicolumn{4}{|c|}{ Благовещенский район } \\
\hline Без миграции & 14,26 & 13,59 & 13,30 \\
\hline Инерционный & 14,26 & 12,94 & 12,33 \\
\hline Умеренный & 14,26 & 12,94 & 12,33 \\
\hline Оптимальный & 14,26 & 12,94 & 12,33 \\
\hline \multicolumn{4}{|c|}{ Караидельский район } \\
\hline Без миграции & 25,29 & 23,93 & 23,25 \\
\hline Инерционный & 25,29 & 22,74 & 21,48 \\
\hline Умеренный & 25,29 & 22,74 & 21,48 \\
\hline Оптимальный & 25,29 & 22,74 & 21,48 \\
\hline \multicolumn{4}{|c|}{ Федоровский район } \\
\hline Без миграции & 16,80 & 16,10 & 15,58 \\
\hline Инерционный & 16,80 & 14,87 & 13,72 \\
\hline Умеренный & 16,80 & 14,87 & 13,72 \\
\hline Оптимальный & 16,80 & 14,87 & 13,72 \\
\hline
\end{tabular}

Источник: Расчеты авторов.

Влияние миграции на возрастную структуру населения городов сравнительно незначительно и особенно заметно на периферийных территориях. В Уфе при инерционном сценарии ожидается рост населения в трудоспособном возрасте ${ }^{3}$ на $3,1 \%$ (без миграции убыль на 3\%). Без миграционного прироста население в этом возрасте в г. Уфа будет снижаться более быстрыми темпами, чем общая численность. При умеренном и оптимальном сценариях рост в указанной возрастной группе несколько меньше. Независимо от варианта сценария численность населения в трудоспособном возрасте г. Стерлитамак будет снижаться (от 3,9\% при умеренном до 4,17\% при инерционном).

Коэффициент демографической нагрузки пожилыми ${ }^{4}$ для Уфимского района составит не больше 467 на 1000 человек трудоспособного населения по всем сценариям развития миграции. Для Стерлитамакского района максимальное значение - 586 на 1000 при инерционном сценарии. Складывается впечатление, что значительного влияния на демографическую нагрузку пожилыми в городах миграция не оказывает, однако понятно, что миграционный прирост способствует более медленному старению населения,

\footnotetext{
${ }^{3}$ Границы трудоспособного возраста приняты следующими: для мужского населения - 15-59 полных лет, для женского населения - 15-54 полных года.

${ }^{4}$ Возрастные границы «населения старше трудоспособного возраста» приняты равными 60+ для мужского населения и 55+ для женского.
} 
смягчению тренда снижения численности населения в трудоспособном возрасте. Вклад миграционной убыли в сравнительно малочисленных Благовещенском, Федоровском и Караидельском районах на возрастную структуру намного более заметен. Демографическая нагрузка пожилыми возрастает до 607 в Благовещенском районе, до 597 в Караидельском районе и до 799 пожилых на 1000 человек трудоспособного населения в Федоровском районе. Значительные потери молодого населения и без того малочисленных районов способствуют изменению возрастной структуры, существенно ускоряя процесс старения.

\section{ЗАКЛЮЧЕНИЕ И РЕКОМЕНДАЦИИ}

В последнее десятилетие в республике продолжается миграционный отток населения из периферийных территорий в городские агломерации, что приводит к значительному росту численности населения пригородных зон. В то же время продолжается и ускоряется старение населения периферийных территорий, в том числе за счет возвратной миграции лиц старшего возраста. В пригородных зонах миграционный прирост наблюдается во всех возрастных группах, как молодых (в результате трудовой и образовательной миграции), так и старших (вследствие привлекательности для них проживания в коттеджных и дачных поселениях пригородов).

При этом старение населения периферийных территорий продолжается и ускоряется не только за счет интенсивного оттока молодого населения, но и за счет возвратной миграции лиц старшего возраста.

Результаты прогнозирования при различных сценариях миграционных процессов показывают, что депопуляции в региональном центре - г. Уфа, а также в пригородных территориях центров агломерации удастся избежать. При этом, если в последнем десятилетии миграция способствовала наращиванию численности населения городаспутника Благовещенска, то в среднесрочной перспективе в городе ожидается снижение его общей численности. Несмотря на смягчение процесса демографического старения в центрах агломераций и их пригородах, миграция не оказывает значительного влияния на демографическую нагрузку. В то же время в малонаселенных периферийных муниципальных районах, в случае сохранения текущих тенденций в миграционных процессах, старение населения ускорится, демографическая нагрузка пожилыми лицами вырастет. Это соответствует общему тренду в Российской Федерации с учетом усиления внутрирегиональных отличий (Петросян и др. 2019: 55-83). В целом результаты перспективного прогноизирования указывают на сильную связь «постарения» населения и миграции. В перспективе с проблемой депопуляции могут столкнуться не только сельские муниципальные районы, но и агломерации республики.

Как было отмечено выше, по оптимальному варианту сценария ожидается усиление полицентричности экономики региона с параллельным развитием Уфимской, ЮжноБашкортостанской и Западной агломераций. Этот вариант развития может иметь такие позитивные последствия, как снижение миграционного оттока трудоспособного населения из периферий, сохранение демографического и трудового потенциала разных типов 
территорий. Именно на такой вариант развития, по нашему мнению, должны быть направлены меры региональной миграционной политики.

Для достижения предложенного оптимального сценария развития миграционных процессов и распределения человеческого капитала предстоит решать взаимосвязанные между собой задачи в сферах экономики, социальной и культурной жизни как ядер агломераций, так и полупериферийных и периферийных территорий. В сфере управления необходима разработка нормативно-правовых актов, регулирующих агломерационное развитие территорий и реализацию проектов межмуниципального сотрудничества с городскими округами - ядрами агломераций.

Особую роль при этом должны сыграть меры в сфере развития транспортной инфраструктуры, улучшения транспортной доступности всех территорий; формирование транспортно-логистической связи населённых пунктов между собой и с ядрами агломераций, т. е. создание единого транспортного каркаса агломераций, значительная часть населения которых включена в учебную и трудовую маятниковую миграцию. По данным опроса 2015 г., в Республике Башкортостан более 20\% молодых жителей сельской местности в возрасте 18-34 лет включены в ежедневные поездки на работу и учебу из населенных пунктов, в которых они проживают (26\% - 18-24 года, 20\% - 25-34 года) (Валиахметов Р.М. и др. 2016: данные социологического исследования).

Важное значение имеют меры в сфере экономического развития и занятости: развитие высокотехнологичных промышленных и сельскохозяйственных предприятий; создание специальных программ для удержания в республике высококвалифицированных специалистов в тех отраслях, которые необходимо развивать в агломерациях.

Равномерному параллельному развитию разных типов территорий, ограничивающему процессы концентрации трудоспособного населения в крупных агломерациях и их пригородах, должны способствовать меры социального развития на периферийных и полупериферийных территориях. Такие меры должны быть направлены на повышение доступности качественных услуг медицины, дошкольного и дополнительного образования, спорта, социальных услуг, обеспеченности качественным жильем, повышение уровня благоустройства развитие уникальных общественных пространств. Целесообразно предусмотреть реализацию мер в сфере жилищного строительства, направленных на опережающее развитие социально-коммунальной инфраструктуры, формирование безопасной, качественной и комфортной среды обитания жителей всех типов территорий, в том числе периферийных.

Это касается не только имеющихся в настоящее время агломераций - Уфимской и Южно-Башкортостанской, но и Западной агломерации (с ядрами в городах Туймазы, Октябрьский, Нефтекамск), а также периферийных территорий городских агломераций с ядрами, расположенными за пределами Башкортостана. 


\section{ЛИТЕРАТУРА}

Ахметова Э.И., Прудников В.Б., Попов Д.В., Шамсутдинова Н.К. (2019). Сценарии пространственного распределения человеческого капитала в Республике Башкортостан: к постановке проблемы. Экономика и управление, 6, 173-176. DOI: https://doi.org/10.34773/EU.2019.6.37.

Башкортостанстат (2019a). Миграџия населения в Республике Башкортостан: статистический сборник. В 2 ч. Ч.1. Уфа: Башкортостанстат.

Башкортостанстат (2019b). Демографические показатели муниципальных образований Республики Башкортостан: статистический сборник. Уфа: Башкортостанстат.

Валиахметов Р.М., Хилажева Г.Ф., Шамсутдинова Н.К. (Ред.) (2016). Республика Башкортостан. Демографический доклад. Выпуск 2. Уфа: Гилем.

Гайнанов Д.А., Уляева А.Г. (2017). Внутрирегиональная миграция как фактор усиления агломерационных процессов. Научное обозрение, 5, 5-13. URL: https://scienceeconomy.ru/ru/article/view?id=961.

Зайончковская Ж.А. (2000). Миграция населения СССР и России в ХХ веке: эволюция сквозь катаклизмы. Проблемы прогнозирования, 4, 1-15.

Исянбаев М.Н. (2008). Экономические подрайонь Республики Башкортостан: приоритетные направления социально-экономического развития. Уфа: Гилем.

Карачурина Л.Б. (2012). Урбанизация по-российски. Отечественные записки, 3, 10-24.

Карачурина Л.Б., Мкртчян Н.В. (2016). Роль миграции в усилении контрастов расселения на муниципальном уровне в России. Известия РАН, Серия географическая, 5, 46-59.

Карачурина Л.Б., Мкртчян Н.В. (2014). Центры и периферия в странах Балтии и регионах Северо-запад России: динамика населения в 2000-е годы. Балтийский регион, 2, 62-80.

Мкртчян Н.В. (2020). Миграция в городах и районах республики Башкортостан: центропериферийные особенности. В Г.Ф. Хилажева, Р.Н. Комлева (Ред.), Демографические чтения (Вызовы и тенденции демографического развития России и ее регионов). Сборник статей Всероссийской научно-практической конференции (Уфа, 22 мая 2020 г.) (сс. 131-135). Уфа: Гилем.

Мкртчян Н.В., Карачурина Л.Б. (2012). Миграционная подвижность молодежи и сдвиги в возрастной структуре населения городов и районов России (1989-2002 годы). В А.А. Агирречу (Ред.), Географическое положение и территориальные структуры: памяти И.М.Майергойза (сс. 688-707). М.: Новый хронограф.

Нефедова Т., Трейвиш А. (2001). Российские городские системы в зеркале эволюционных теорий урбанизации. В Т. Нефедова, П. Полян, А. Трейвиш (Ред.), Город и деревня 8 Европейской России: сто лет перемен (сс.171-194). М.: ОГИ.

Петросян А.Н., Шевчук Е.И., Кириллов П.Л., Мозгунов Н.А. (2019). Географические особенности старения населения России. Демографическое обозрение, 6(2), 55-83. DOI: https://doi.org/10.17323/demreview.v6i2.9872.

Пивоваров Ю.Л. (2001). Урбанизация России в XX веке: представления и реальность. Общественные науки и современность, 6, 101-113.

Трейвиш А.И. (2016). Сельско-городской континуум: судьба представления и его связь с пространственной мобильностью населения. Демографическое обозрение, 3(1), 52-70. DOI: https://doi.org/10.17323/demreview.v3i1.176. 
Gibbs J. (1963). The evolution of population. Economic Geography, 2, 85-99.

Klaassen L.H., Schimemi G. (1981). Theoretical issues in urban dynamics. In L.H. Klaassen et al. (Eds.), Dynamics of urban development (pp. 8-28.). Gower, Aldershot, UK. 


\title{
THE EFFECT OF MIGRATION ON POPULATION SIZE AND AGE COMPOSITION IN MUNICIPALITIES OF DIFFERENT TYPES IN BASHKORTOSTAN
}

\author{
NAILYA SHAMSUTDINOVA, VADIM PRUDNIKOV, \\ IRINA UTIASHEVA, GULDAR KHILAZHEVA
}

\begin{abstract}
The paper assesses the impact of migration on the size and age structure of the population of different municipalities in the Republic of Bashkortostan. We distinguish «core municipalities» (industrial and education centers, which are likely to attract human capital); municipalities adjacent to the core municipalities (where the population is growing due to the proximity to the core, suburban territories); and peripheral areas, where the migration outflow within the Ufa and South Bashkortostan agglomerations is irreversible. At the first stage, a retrospective prediction was made for the selected types of municipalities for the period 2008-2018. First of all, suburban territories are likely to gain the most from current migration trends even in comparison with the core municipalities. This causes an increase in population size in almost all age groups, primarily among the population of pre-retirement and retirement age. At the second stage, we carried out the population projection of the selected types of municipalities for the period up to 2029. Four migration scenarios are considered. The results show that a population increase in core municipalities and suburban areas could only persist in the case of permanent migration inflow from peripheral areas. However, this inflow would not change the age structure of the population in core and suburban municipalities dramatically. At the same time, the peripheral areas would continue to decrease in population and would significantly «age». Thus, the development of core and suburban territories is associated with a loss of demographic potential in peripheral areas. As a result, a slowdown in population growth in core territories and an increase in intraregional differentiation are expected.
\end{abstract}

Key words: migration growth, age structure, forecasting, Ufa agglomeration, South Bashkortostan agglomeration, core territories, peripheral territories.

NaILYA Shamsutdinova (shamsutdinovank@gmail.com), InSTitute FOR STRATEGIC STUdies OF THE REPUbLic OF BASHKORTOSTAN, RUSSIA.

VAdim Prudnikov (prudnikov.bgu@mail.ru), BASHKIR STATE University, RusSia.

IRINA UTYASHEVA (utasheva@bashstat.ru), InSTITUTE FOR STRATEGIC STUDIES OF THE REPUBLIC OF BASHKORTOSTAN, RUSSIA.

GULDAR KHILAZHEVA (aguldar@yandex.ru), INSTITUTE FOR STRATEGIC STUdies Of THE REPUblic OF BASHKORTOSTAN, RUSSIA.

THE PROJECT WAS PREPARED WITH THE SUPPORT OF THE RUSSIAN FOUNDATION FOR BASIC RESEARCH AND THE REPUBLIC OF BASHKORTOSTAN, PROJECT NO. 17-46-020237 "STUDY OF TRENDS AND FACTORS AFFECTING THE INTERACTION BETWEEN CENTRAL AND PERIPHERAL SYSTEMS (THE EXAMPLE OF THE REPUBLIC OF BASHKORTOSTAN)”.

DATE RECEIVED : MAY 2020.

\section{REFERENCES}

Akhmetova E.I., Prudnikov V.B., Popov D.V., SHamsutdinova N.K. (2019). Stsenarii prostranstvennogo raspredeleniya chelovecheskogo kapitala v Respublike Bashkortostan: k postanovke problemy. Economics and Management: Research and Practice Journal, 12, 173-176. (In Russ.). DOI: https://doi.org/10.34773/EU.2019.6.37. 
Bashkortostanstat (2019a). Migratsiya naseleniya v Respublike Bashkortostan: statisticheskiy sbornik. In 2 ch. Ch.1. Ufa: Bashkortostanstat. (In Russ.).

Bashkortostanstat (2019b). Demograficheskiye pokazateli munitsipal'nykh obrazovaniy Respubliki Bashkortostan: statisticheskiy sbornik. Ufa: Bashkortostanstat. (In Russ.).

Gaynanov D.A., Ulyayeva A.G. (2017). Vnutriregional'naya migratsiya kak faktor usileniya aglomeratsionnykh protsessov. Nauchnoye obozreniye, 5, 5-13. Retrieved from https://science-economy.ru/ru/article/view?id=961 (In Russ.).

Gibbs J. (1963). The evolution of population. Economic Geography, 2, 85-99.

Isyanbayev M.N. (2008). Ekonomicheskiye podrayony Respubliki Bashkortostan: prioritetnyye napravleniya sotsial'no-ekonomicheskogo razvitiya. Ufa: Gilem. (In Russ.).

Karachurina L.B. (2012). Urbanizatsiya po-rossiyski. Otechestvennyye zapiski, 3, 10-24. (In Russ.).

Karachurina L.B., Mkrtchyan N.V. (2016). Rol' migratsii v usilenii kontrastov rasseleniya na munitsipal'nom urovne v Rossii. Izvestiya Rossiiskoi Akademii Nauk. Seriya Geograficheskaya, 5, 46-59. (In Russ.).

Karachurina L.B., Mkrtchyan N.V. (2014). TSentry i periferiya v stranakh Baltii i regionakh Severo-zapad Rossii: dinamika naseleniya v 2000-e gody. Baltiyskiy region, 2, 62-80. (In Russ.).

Klaassen L.H.. Schimemi G. (1981). Theoretical issues in urban dynamics. In L.H. Klaassen et al. (Eds.). Dynamics of urban development (pp. 8-28.). Gower, Aldershot, UK.

Mkrtchyan N.V. (2020). Migratsiya v gorodakh i rayonakh respubliki Bashkortostan: tsentroperiferiynyye osobennosti. In G.F. KHilazheva, R.N. Komleva (Eds.), Demograficheskiye chteniya (Vyzovy i tendentsii demograficheskogo razvitiya Rossii i eye regionov). Sbornik statey Vserossiyskoy nauchno-prakticheskoy konferentsii (Ufa, 22 maya 2020 g.) (pp. 131135). Ufa: Gilem. (In Russ.).

Mkrtchyan N.V., Karachurina L.B. (2012). Migratsionnaya podvizhnost' molodezhi i sdvigi v vozrastnoy strukture naseleniya gorodov i rayonov Rossii (1989-2002 gody). In A.A. Agirrechu (Ed.), Geograficheskoye polozheniye i territorial'nyye struktury: pamyati I.M.MayYErgoyza (pp. 688-707). Moscow: Novyy khronograf. (In Russ.).

Nefedova T., Treyvish A. (2001). Rossiyskiye gorodskiye sistemy v zerkale evolyutsionnykh teoriy urbanizatsii. In T. Nefedova, P. Polyan, A. Treyvish (Eds.), Gorod i derevnya v Evropeyskoy Rossii: sto let peremen (pp.171-194). Moscow: OGI. (In Russ.).

Petrosyan A.N., SHevchuk E.I., Kirillov P.L., Mozgunov N.A. (2019). Geograficheskiye osobennosti stareniya naseleniya Rossii. Demographic Review, 6(2), 55-83. Retrieved from https://doi.org/10.17323/demreview.v6i2.9872 (In Russ.).

Pivovarov YU.L. (2001). Urbanizatsiya Rossii v XX veke: predstavleniya i real'nost'. Obshchestvennyye nauki i sovremennost', 6, 101-113. (In Russ.).

Treyvish, A.I. (2016). Sel'sko-gorodskoy kontinuum: sud'ba predstavleniya i ego svyaz' s prostranstvennoy mobil'nost'yu naseleniya. Demographic Review, 3(1), 52-70. Retrieved from https://doi.org/10.17323/demreview.v3i1.176. (In Russ.).

Valiakhmetov R.M., Khilazheva G.F., Shamsutdinova N.K. (Red.) (2016). Respublika Bashkortostan. Demograficheskiy doklad. Vypusk 2. Ufa: Gilem. (In Russ.).

Zayonchkovskaya ZH.A. (2000). Migratsiya naseleniya SSSR i Rossii v XX veke: evolyutsiya skvoz' kataklizmy. Studies on Russian Economic Development, 4, 1-15. (In Russ.). 